\title{
Testicular Seminoma
}

National Cancer Institute

\section{Source}

National Cancer Institute. Testicular Seminoma. NCI Thesaurus. Code C7328.

A malignant germ cell tumor arising from the testis. It is believed that it is derived from the sexually undifferentiated embryonic gonad. Treatment with radiotherapy is highly successful when the tumor is diagnosed in localized stages, which represents the majority of presentations of seminoma. 